\title{
Penerapan Algoritma C4.5 pada Pengaruh Iklan Tanpa Label Harga di Instagram
}

\author{
Ratnawati*, Fransisca Natalia \\ Program Studi Sistem Informasi Akuntansi, Fakultas Teknik dan Informatika, \\ Universitas Bina Sarana Informatika Kampus Kabupaten Karawang \\ Jl. Banten No.1, Karangpawitan, Karawang, Jawa Barat \\ Jl. Letjen Sutoyo No.43, Cengklik, Nusukan, Kec. Banjarsari, Kota Surakarta, Jawa Tengah \\ *e-mail: ratnawati.rtx@bsi.ac.id
}

(received: 16 November 2020, Direvisi: revised: Desember 2020,accepted:17 Desember 2020)

\begin{abstract}
Abstrak
Saat ini banyak strategi promosi yang beralih ke media online, salah satunya instagram. Hal ini dimanfaatkan oleh para perodusen untuk menjadikan instagram sebagai media promosi yang potensial. Ada satu jenis iklan yang menarik di instagram, yakni jenis iklan yang menampilkan keunggulan produknya namun tidak menampilkan label harga. Oleh karena itu peneliti tertarik untuk meneliti apakah jenis iklan ini dapat mempengaruhi konsumen dalam melakukan pembelian produk yang diiklankan. Metode yang peneliti gunakan adalah data mining dengan algoritma C4.5 dimana data yang diperoleh adalah dengan menyebarkan kuesioner kepada 200 responden pengguna instagram aktif berdasarkan jenis kelamin. Kuesioner dirancang berdasarkan terori AISAS yang biasa digunakan untuk mengukur tingkat efektivitas iklan di media online dengan atribut penelitian yaitu jenis kelamin, Attention, Interest, Search dan Action. Hasil penelitian dengan algoritma C4.5 ini diketahui bahwa tingkat akurasi dari model yang dibentuk mencapai $88.5 \%$ dan nilai AUC sebesar 0.82 dimana nilai ini termasuk kedalam rentang Good Classification. Sedangkan atribut yang paling mempengaruhi adalah atribut Search yang memiliki nilai gain tertinggi diantara atribut lainnya.
\end{abstract}

Kata Kunci: Teori AISAS, pengaruh iklan, data mining, algoritma c4.5, iklan instagram

\section{Abstract}

Currently, many promotional strategies are turning to online media, one of them is Instagram. This is used by producers to make Instagram a potential promotional media. There is one type of ad that is interesting on Instagram, which is a type of ad that displays the advantages of its product but does not display a price tag. Therefore, researchers are interested in examining whether this type of advertisement can influence consumers in purchasing the advertised product. The method that researchers use is data mining with the C4.5 algorithm where the data obtained is by distributing questionnaires to 200 respondents who are active Instagram users based on gender. The questionnaire was designed based on the AISAS theory which is commonly used to measure the level of effectiveness of advertisements in online media with research attributes, namely gender, attention, interest, search and action. The results of the research with the C4.5 algorithm show that the accuracy rate of the model formed reaches $88.5 \%$ and the AUC value is 0.82 where this value is included in the Good Classification range. While the most influencing attribute is the Search attribute which has the highest gain value among other attributes.

Keywords: AISAS theory, effect of advertising, data mining, c4.5 algorithm, instagram ads

\section{Pendahuluan}

Promosi merupakan salah satu unsur yang memegang peranan penting dalam sebuah usaha. Dengan adanya promosi maka pengusaha dapat menginformasikan serta mempengaruhi target konsumen untuk akhirnya membeli produk yang dijualnya. Media promosi online menjadi salah satu peluang yang banyak digunakan karena didukung dengan semakin meningkatnya jumlah pengguna internet dan media sosial. Salah satu media sosial yang banyak digunakan di indonesia adalah 
instagram. Menurut data yang dirilis Napoleon Cat, pada periode Januari-Mei 2020, pengguna Instagram di Indonesia mencapai 69,2 juta (69.270.000) pengguna[1]. Hal ini membuka peluang besar bagi para pelaku usaha untuk mencoba memasang iklan melalui instagram. Ada beberapa jenis iklan di instagram seperti iklan menggunakan foto, iklan dengan video, iklan carousel dan iklan story. Dalam penyajiannya pun dapat berbeda-beda, salah satu teknik penyajian iklan yang menjadi perhatian adalah iklan produk di instagram yang tidak langsung memberikan informasi harga kepada target konsumennya, yakni dimana konsumen akan diarahkan untuk menghubungi kontak penjual yang tertera dalam deskripsi iklan tersebut. Biasanya produk-produk yang ditawarkan adalah produk yang tidak dijual bebas di toko-toko atau tempat jual beli lainnya. Oleh karena itu peneliti tertarik untuk mengetahui apakah jenis iklan tanpa informasi harga ini dapat berpengaruh terhadap pola pembelian konsumen. Dengan demikian, tujuan dari penelitian ini adalah mengetahui pengaruh iklan tanpa label harga di instagram terhadap pola pembelian konsumen melalui iklan tersebut.

\section{Tinjauan Literatur}

\subsection{Penelitian Terdahulu}

Beberapa penelitian terdahulu tentang pengaruh iklan di instagram diantaranya adalah penelitian [2] variabel yang digunakan adalah attitude towards the ad, ad recall dan clik throught rates. Faktor Ad Recall merupakan faktor yang paling dominan dalam mempengaruhi minat beli konsumen. Penelitian lain [3] tentang penggunaan iklan di instagram dimana penelitian ini menggunakan variabel penelitian yaitu attitude towards the ad, ad recall dan click through rates. Hasilnya adalah variabel Ad Recall menjadi variabel paling berpengaruh terhadap pembelian konsumen. Selain itu ada pula penelitian dengan judul Pengaruh Intensitas Melihat Iklan di Instagram terhadap Pengetahuan dan Perilaku Konsumtif Remaja Putri[4] menjelaskan bahwa intensitas melihat iklan di instagram berpengaruh terhadap perilaku konsumtif para remaja putri yang membeli produk kosmetik. Metode yang digunakan adalah Metode penelitian kuantitatif dengan teori AIDDA (Attention, Interest, Desire, Decision,Action).

Penelitian[5] yang membuktikan terdapat indikator minat beli konsumen berpengaruh signifikan terhadap keputusan pembelian dengan menggunakan variabel laten eksogen digambarkan melalui variabel instagram. Sedangkan variabel laten endogen digambarkan dengan e-wom, minat beli, keputusan pembelian. Variabel manifes terdiri atas Attention, Interest, Desire, Action, Intensity ewom, Valence of opinion, Content of e-wom, Advice seeking, Minat trasaksional, Minat refresial, Minat preferensial, Minat eksploratif, Pengenalan Masalah, Pencarian informasi, Evaluasi alternatif, Keputusan pembelian. Dari beberapa penelitian terdahulu banyak penelitian yang membuktikan efektivitas penggunaan instagram sebagai media promosi, namun belum ada penelitian yang membahas secara khusus jenis iklan seperti apa yang digunakan dalam promosi tersebut.

\subsection{Teori AISAS}

Teori AISAS ada lima dimensi yaitu Attention, Interest, Search, Action, dan Share. Dimana dalam metode ini AISAS membuat konsumen menjadi sadar dan perhatian terhadap produk (Attention), menjadi tertarik (Interest), mencari informasi yang benar melalui internet (Search), membeli produk (Action) dan mengirimkan ulasan setelah menggunakan produk (Share). Model AISAS merupakan bagian dari perkembangan model AIDMA (Attention, Interest, Desire, Memory, Action) yang diusulkan oleh S. Roland Hall guna mempresentasikan proses respon dari konsumen. AIDMA merupakan tindakan yang diambil oleh orang-orang yang menonton iklan TV dari perilaku belanja di toko-toko [13].

Saat membutuhkan suatu produk dengan keterlibatan yang tinggi, konsumen akan melakukan pencarian yang lebih lama dibandingkan produk-produk dengan keterlibatan yang rendah. Oleh karena itu, Dentsu [11] mengemukakan sebuah model komunikasi pemasaran yang didapat dari perkembangan teknologi, yang diberi nama dengan model AISAS (Attention $\rightarrow$ Interest $\rightarrow$ Search $\rightarrow$ Action $\rightarrow$ Share).

Dengan menggunakan teori AISAS, kita dapat melihat bahwa konsumen sebagai orang yang aktif, dimana konsumen dapat melakukan pencarian terhadap informasi serta membagikan informasi yang sudah didapat kepada orang lain. Konsep AISAS adalah sebagai berikut: [12]. 
a. Attention Pesan atau iklan harus menarik perhatian bagi konsumen yang menjadi sasarannya, oleh karena itu pesan atau iklan memerlukan bantuan seperti ukuran, penggunaan warna, tata letak, jenis huruf, serta berbagai suara khusus untuk iklan radio dan televisi. Hal pokok dan sangat perlu diperhatikan adalah bahwa perhatian calon konsumen harus didapatkan.

b. Interest, Setelah perhatian apakah pesan sudah berhasil disampaikan? Persoalan yang dihadapi adalah apakah konsumen memiliki keingintahuan dan minat yang lebih. Dengan ini konsumen harus dirangsang agar mau membaca dan mengikuti pesan-pesan yang disampaikan agar lebih tertarik terhadap ilkan tersebut.

c. Search, Dengan adanya mesin pencari, dan sebelum konsumen mengambil keputusan, maka konsumen akan mencari informasi sebanyak-banyaknya melalui search engine. Product review, tulisan di blogs, website-website lain, dan semua informasi akan muncul dengan jelas inilah yang akan membantu konsumen untuk mengambil keputusan.

d. Action, Adalah tindakan konsumen, pada tahap ini Proses interaksi langsung antara konsumen dengan sales terjadi seperti melakukan pemesanan, pembayaran/transaksi, pengiriman, dan penerimaan barang, hingga selesainya semua transaksi merupakan satu kesatuan pengalaman yang benar-benar harus dipertahankan dan dijaga agar sesuai dengan keinginan konsumen bahkan melebihi ekspektasi dari konsumen.

e. Share adalah proses terakhir dari action setelah konsumen merasakan semua pengalaman interaksi/komunikasi mereka dengan produk atau brand, diharapkan konsumen akan membagi pengalamannya kepada orang lain melalui email, chat, blogs, online forum, dan lain-lain. Sehingga pengalaman baik ataupun buruk akan mudah tersebar.

\subsection{Instagram Ads}

Iklan di instagram atau biasa disebut Instagram $A d s$ adalah salah satu media promosi yang banyak diminati oleh para pelaku usaha. Iklan instagram atau Instagram Ads adalah sebuah kegiatan pemasangan iklan melalui media instagram dengan tujuan untuk menjangkau target konsumen yang lebih luas[6].Layanan Instagram ads adalah fitur layanan iklan yang bisa membuat para pelaku bisnis memasang iklan secara langsung di Instagram[7]. Para pelaku usaha dapat memasang iklan di instagram baik dalam bentuk foto, video, Carousel Ads (iklan dengan menggunakan beberapa gambar secara bersamaan) dan juga instagram stories.

Instagram Ads memiliki banyak kelebihan, antara lain pemasangan iklah di instagram terlihat seperti unggahan foto atau video biasa sehingga pengguna instagram tidak merasa terlalu kontras seperti iklan pada platform lain. Selain itu saat ini instagram dapat memberikan kemudahan kepada pemasang iklan untuk memilih pangsa pasar yang spesifik. Hal ini dikarenakan instagram telah diakuisisi oleh facebook. Kelebihan lain adalah adanya fitur follow yang dapat dimanfaatkan oleh pemasang ikan untuk memberikan iklan lebih intens kepada pengguna instagram yang mengikuti akun pemasang iklan tersebut.

\subsection{Data Mining}

Data mining adalah proses menemukan pola dan pengetahuan menarik dari data dalam jumlah besar [8]. Pengertian lain menyebutkan bahwa data mining adalah sebuah ekstraksi informasi yang tersirat, yang belum diketahui sebelumnya, dan berpotensi bermanfaat dari data[9]. Tidak dapat dipungkiri bahwa setiap hari dalam menjalankan sehari-hari manusia menghasilkan data sehingga semakin lama data tersebut semakin banyak, oleh karena itu penggunaan data mining dapat dimanfaatkan untuk menggali pengetahuan baru dari data yang besar.

Secara umum terdapat 5 (lima) peranan dalam data mining, yaitu estimasi, prediksi, klasifikasi, clustering, dan asosiasi[10]. Sejumlah data besar yang akan diolah menjadi informasi baru dengan menggunakan teknik data mining ini memerlukan algoritma. Dari lima peranan data mining yang telah disebutkan di atas masing-masing menggunakan algoritma yang berbeda untuk pengolahan datanya. Data mining yang berperan dalam estimasi dan prediksi banyak menggunakan algoritma Support Vector Machine (SVM) dan Neural Network. Sedangkan untuk peran klasifikasi algoritma yang banyak digunakan antara lain k-Nearest Neighbors (k-NN), Naive Bayes, ID3, C4.5 dan lainlain. Algoritma yang digunakan untuk peran clustering antara lain K-Means, Fuzzy C-Means Self- 
Organization Map (SOM) dan lain-lain. Sedangkan untuk peran asosiasi algoritma yang banyak digunakan adalah A Priori, Chi Square dan masih banyak lagi.

\subsection{Algoritma C4.5}

Algoritma C4.5 adalah teknik algoritma klasifikasi dalam membentuk model pohon keputusan [11]. Algoritma C4.5 merupakan pengembangan atau hasil induksi dari algoritma sebelumnya yang dikambangkan oleh J. Ross Quinlan yakni algoritma ID3, dimana masukan data berupa sampel training, label training serta atribut dari algoritma C4.5[12]. Dalam melakukan proses pembentukan pohon keputusan terdapat empat proses yang harus dilalui yakni [12]:

1. Menentukan sebuah atribut yang memiliki nilai gain tertinggi sebagai node akar.

2. Setiap node yang ada dibuatkan cabang masing-masing.

3. Setiap kasus dibagi menjadi satu cabang.

4. Ulangi proses percabangan sehingga setiap class memiliki nilai yang sama.

Algoritma C4.5 merupakan salah satu algoritma data mining yang digunakan untuk membuat pohon keputusan atau decision tree. Dalam sebuah pohon keputusan proses yang dilakukan adalah dengan membagi data besar menjadi record-record yang lebih kecil disertai dengan rule atau aturan yang mengacu pada keputusan [13]. Dari pohon keputusan tersebut dapat menampilkan sebuah pola atau aturan yang mudah difahami oleh bahasa sehari-hari. Pohon keputusan tersebut dibentuk berdasarkan atribut yang nantinya akan menjadi sebuah parameter dalam pembentukan aturan atau pola tersebut. Di dalam sebuah decision tree, akar (root) tertinggi adalah atribut utama yang menentukan pembentukan akar selanjutnya. Pada algoritma C4.5 akar tertinggi dapat dilihat dari nilai gain tertinggi di antara atribut-atribut yang ada. Nilai gain dapat dihitung dengan persamaan (1) berikut ini:

$$
\operatorname{Gain}(A)=\operatorname{Entropi}(S)-\sum_{i=1}^{k} \frac{|S i|}{|S|} \times \operatorname{Entropi}(S i)
$$

Keterangan :

$\mathrm{S}:$ kasus

A : atribut

$\mathrm{k}$ : jumlah partisi atribut ke-A

|Si|: jumlah kasus partisi ke-i

$|S|$ : jumlah kasus pada $S$

Untuk menghasilkan nilai gain, maka harus diketahui terlebih dahulu nilai entropinya. Nilai entropi setiap atribut dapat diketahui dengan persamaan (2) berikut:

Entropi $(S)=\sum_{j=1}^{k}-p j \log 2 p j$

Keterangan :

$\mathrm{S}:$ himpunan kasus

$\mathrm{k}$ : jumlah partisi hipunan $\mathrm{S}$

$\mathrm{Pj}$ : kasus partisi ke-j

\section{Metode Penelitian}

Metode yang penulis gunakan merupakan metode terapan menggunakan data mining yang terdiri dari proses standar dalam penerapan data mining yang dapat diterapkan oleh berbagai sektor industri yang dikenal dengan istilah CRISP-DM (CRoss-Industry Standard Process for Data Mining). Adapun langkah-langkahnya adalah sebagai berikut[14]:

a. Business Understanding

Tujuan dari penelitian ini adalah untuk mengetahui apakah iklan tanpa label harga yang dipasang di instagram dapat mempengaruhi pola pembelian produk oleh konsumen. Oleh karena itu yang menjadi sasaran pada penelitian ini adalah para pengguna instagram aktif.

b. Data Understanding

Pada tahap pemahaman data ini metode yang digunakan dalam penelitian ini adalah survey, guna untuk mengumpulkan informasi mengenai variabel dan responden yang dianggap sebagai sekelompok populasi (obyek) dengan menggunakan kuesioner. Populasi dalam penelitian ini, 
adalah tidak diketahui, tetapi ditujukan kepada para pengguna Instagram aktif. Sampel yang akan digunakan dalam penelitian adalah responden yang berdasarkan pada jenis kelamin. Metode sampel pada penelitian ini adalah purposive sampling sebagai teknik pengambilan sampel, yaitu metode penetapan responden untuk dijadikan sampel berdasarkan atas kriteria [11] Kriteria responden yang dimaksud dalam penelitian ini adalah mereka yang menggunakan Instagram aktif dan berdasarkan pada jenis kelaminnya. Jumlah sampel yang diambil adalah 200 responden Adapun yang menjadi indikator pada kuesioner tersebut adalah dengan menggunakan konsep untuk mengukur tingkat efektivitas iklan di media online.

c. Data Preparation

Setelah peneliti mendapatkan sejumlah data, langkah selanjutnya adalah mempersiapkan data tersebut sebelum dilakukan pemodelan dengan data mining. Penyiapan data pada penelitian ini adalah dengan menentukan nilai-nilai yang didapatkan dari hasil kuesioner ke dalam variabelvariabel penelitian. Adapaun variabel yang digunakan adalah Attention (perhatian), Interest (ketertarikan), Search (pencarian) serta Action (pembelian). Variabel attantion digunakan untuk mengukur seberapa sering pengguna instagram melihat iklan tanpa label harga di timeline instagramnya. Variabel interest digunakan untuk mengukur seberapa sering pengguna instagram membaca caption atau informasi promosi pada iklan tanpa label harga. Variabel search digunakan untuk mengukur seberapa sering pengguna instagram mencari informasi lanjutan bahkan menghubungi pengiklan untuk mencari informasi tentang produk yang diiklankan. Sedangkan variabel action digunakan untuk mengukur seberapa sering pengguna instagram melakukan pembelian dari produk yang diiklankan tersebut.

d. Modeling

Menentukan algoritma merupakan tahap selanjutnya yakni tahap modeling. Pada tahap ini peneliti menggunakan algoritma decision tree $\mathrm{C} 4.5$ untuk mendapat gambaran atau rule bagaimana pola pembelian yang dilakukan oleh konsumen yang dipengaruhi oleh tayangan iklan tanpa label harga di instagram. Dari model ini akan dapat terlihat variabel apa yang sangat berpengaruh terhadap tindakan pembelian produk oleh pengguna instagram, sehingga hal ini juga dapat dijadikan kesimpulan apakah penggunaan iklan tanpa label harga di instagram dapat dinilai efektif untuk digunakan oleh para pengiklan.

e. Evaluation

Peroses evaluasi dilakukan dengan menerapkan pengujian cross validation pada model yang digunakan untuk mendapatkan confusion matrix dan ROC curve sehingga dapat diketahui tingkat akurasi dari rule yang terbentuk. Confusion matrix dapat digunakan untuk menggambarkan seberapa baik sebuah klasifikasi dilakukan. Sedangkan ROC curve merupakan kurva yang menggambarkan pemisahan antar class yang berbeda. Dalam penelitian ini class yang terbentuk adalah class "Ya" yang artinya melakukan pembelian dan class "Tidak" yang berarti tidak melakukan pembelian. Tahapan penelitian yang dilakukan dapat terlihat pada Gambar 1 di bawah ini:

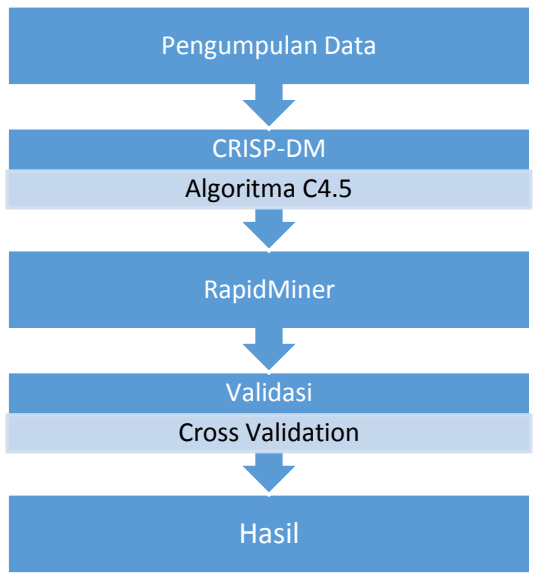

Gambar 1. Tahapan Penelitian 


\section{Hasil dan Pembahasan}

\subsection{Business Understanding}

Pemasangan iklan pada media online merupakan salah satu strategi pemasaran yang cukup efektif karena pengguna media online memiliki jumlah yang sangat banyak. Instagram merupakan salah satu media online yang banyak digunakan khususnya oleh masyarakat Indonesia. Pengiklan dapat memposting iklan produknya dalam berbagai format seperti gambar, video atau gabungan keduanya. Untuk menarik minat pembeli, biasanya pengiklan akan menggunakan desain iklan yang menarik. Namun ada salah satu jenis desain iklan di instagram yang hanya memperkenalkan produk serta keunggulannya tanpa memberikan informasi harga pada iklan tersebut. Dengan adanya penelitian ini maka diharapkan dapat memberikan manfaat bagi pengiklan apakah jenis iklan tanpa label harga ini dapat dijadikan pilihan dalam mengiklankan produknya dengan membaca pola pembelian konsumen.

\subsection{Data Understanding}

Dalam penyebaran kuesioner yang dilakukan peneliti kepada 200 orang responden, tabel 1 berikut ini adalah keterangan atribut kuesioner yang disebarkan:

Tabel 1. Atribut Kuesioner

\begin{tabular}{|c|c|c|}
\hline No & Atribut & Keterangan \\
\hline 1 & Jenis kelamin & Laki-laki/Perempuan \\
\hline \multirow[t]{4}{*}{2} & Attention (Perhatian) & \multirow{4}{*}{$\begin{array}{l}\text { Tidak pernah, Jarang, } \\
\text { kadang, sering, sangat } \\
\text { sering }\end{array}$} \\
\hline & $\begin{array}{l}\text { a. Melihat iklan produk tanpa harga di timeline } \\
\text { instagram }\end{array}$ & \\
\hline & b. Melihat cara pembelian produk & \\
\hline & c. Melihat informasi promosi & \\
\hline \multirow[t]{4}{*}{3} & Interest (ketertarikan) & \multirow{4}{*}{$\begin{array}{l}\text { Tidak pernah, Jarang, } \\
\text { kadang, sering, sangat } \\
\text { sering }\end{array}$} \\
\hline & $\begin{array}{l}\text { a. membaca bio/timeline dari instagram produk } \\
\text { yang dijual }\end{array}$ & \\
\hline & b. membaca caption iklan & \\
\hline & c. tertarik dengan informasi promosi iklan & \\
\hline \multirow[t]{4}{*}{4} & Search (pencarian) & \multirow{4}{*}{$\begin{array}{l}\text { Tidak pernah, Jarang, } \\
\text { kadang, sering, sangat } \\
\text { sering }\end{array}$} \\
\hline & $\begin{array}{l}\text { a. Mencari informasi atau menghubungi pihak } \\
\text { pengiklan terkait harga produk }\end{array}$ & \\
\hline & $\begin{array}{l}\text { b. Mencari informasi atau menghubungi pihak } \\
\text { pengiklan terkait berbagai model produk }\end{array}$ & \\
\hline & $\begin{array}{l}\text { c. Mencari informasi atau menghubungi pihak } \\
\text { pengiklan terkait cara pembelian online }\end{array}$ & \\
\hline 5 & Action (pembelian) & Ya atau Tidak \\
\hline
\end{tabular}

\subsection{Data Preparation}

Data yang telah terkumpul diolah terlebih dahulu dengan meterjemahkan data dengan skala interval menjadi kembali ke data ordinal, sehingga didapatkan data yang siap untuk dimodelkan. Data yang telah disiapkan digambarkan pada Tabel 2 berikut ini: 
Tabel 2. Data Hasil Kuesioner

\begin{tabular}{lllllc}
\hline No & Jenis Kelamin & \multicolumn{1}{c}{ Attention } & \multicolumn{1}{c}{ Interest } & \multicolumn{1}{c}{ Search } & Action \\
\hline $\mathbf{1}$ & Perempuan & Sering & Sering & Jarang & Ya \\
\hline $\mathbf{2}$ & Perempuan & Sering & Jarang & Kadang & Ya \\
\hline $\mathbf{3}$ & Perempuan & Kadang & Tidak Pernah & Jarang & Ya \\
\hline $\mathbf{4}$ & Perempuan & Kadang & Sering & Sering & Ya \\
\hline $\mathbf{5}$ & Perempuan & Sangat Sering & Kadang & Jarang & Tidak \\
\hline$\ldots$ & $\ldots$ & $\ldots$ & $\ldots$ & $\ldots$ & $\ldots$ \\
\hline $\mathbf{\ldots}$ & $\ldots$ & $\ldots$ & $\ldots$ & $\ldots$ & $\ldots$ \\
\hline $\mathbf{2 0 0}$ & Laki-laki & Kadang & Jarang & Jarang & Ya \\
\hline
\end{tabular}

\subsection{Modeling}

a. Pemodelan dengan cross validation

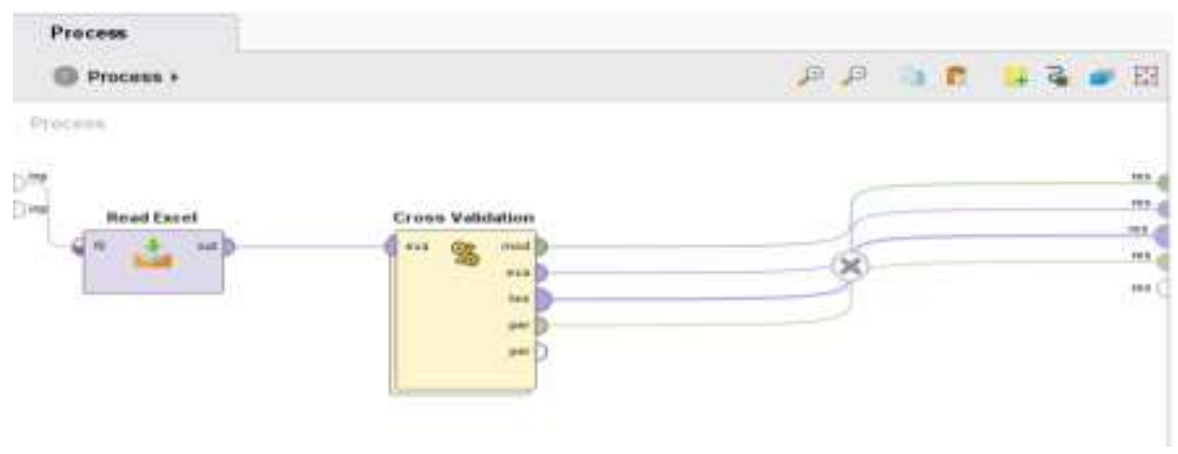

Gambar 2. Tahap Modeling Dengan Cross Validation

Gambar 2. Menunjukan bahwa validasi pada proses modeling dengan jenis cross validation yang berhubungan langsung dengan data yang sebelumnya telah dipersiapkan pada MS. Excel.

b. Pemodelan menggunakan algoritma Decision Tree $\mathrm{C} 4.5$

c.

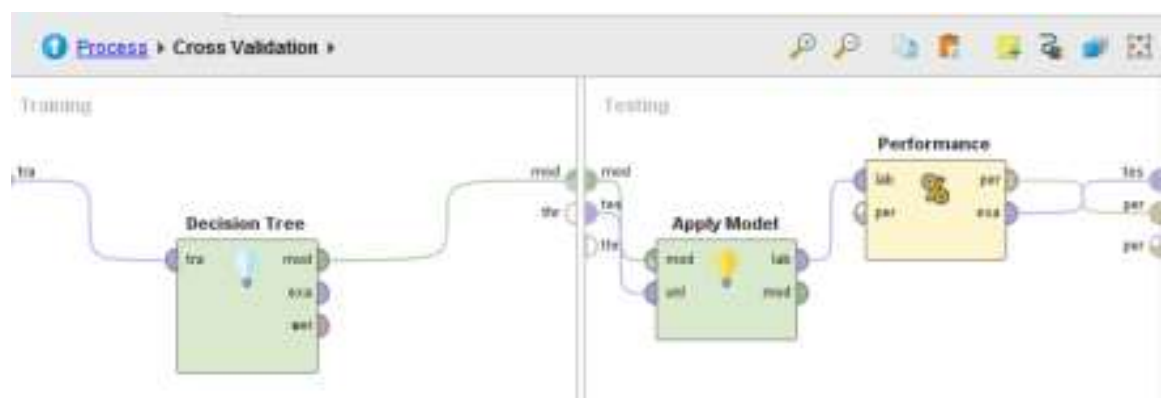

Gambar 3. Proses Modeling Dengan Algoritma Decision Tree C4.5

Pada Gambar 2. Algoritma decision tree dihubungkan dengan operator apply model yang berfungsi untuk menghubungkan penerapan algoritma decision tree tersebut ke operator performace untuk mengevaluasi statistik pada kinerja klasifikasi yang dilakukan. 
d. Pohon Keputusan

Tabel 3. Nilai Entropi dan Gain

\begin{tabular}{|c|c|c|c|c|c|c|}
\hline \multicolumn{2}{|c|}{ Attribute } & Jumlah & $\mathbf{Y a}$ & Tidak & Entropi & Gain \\
\hline \multirow[t]{3}{*}{ Total } & & 200 & 176 & 24 & 0,529361 & \\
\hline & & & & & & 0,000914 \\
\hline & Laki-laki & 42 & 36 & 6 & 0,591673 & \\
\hline \multirow[t]{6}{*}{ Jenis Kelamin } & Perempuan & 158 & 140 & 18 & 0,51164 & \\
\hline & & & & & & 0,028522 \\
\hline & Sangat Sering & 15 & 13 & 2 & 0,56651 & \\
\hline & Sering & 57 & 49 & 8 & 0,585157 & \\
\hline & Kadang & 79 & 75 & 4 & 0,289079 & \\
\hline & Jarang & 41 & 32 & 9 & 0,759276 & \\
\hline \multirow[t]{6}{*}{ Attention } & Tidak Pernah & 8 & 7 & 1 & 0,543564 & \\
\hline & & & & & & 0,038949 \\
\hline & Sangat Sering & 8 & 7 & 1 & 0,543564 & \\
\hline & Sering & 40 & 37 & 3 & 0,384312 & \\
\hline & Kadang & 83 & 78 & 5 & 0,328401 & \\
\hline & Jarang & 54 & 44 & 10 & 0,69129 & \\
\hline \multirow[t]{6}{*}{ Interest } & Tidak Pernah & 15 & 10 & 5 & 0,918296 & \\
\hline & & & & & & 0,084443 \\
\hline & Sangat Sering & 0 & 0 & 0 & 0 & \\
\hline & Sering & 33 & 33 & 0 & 0 & \\
\hline & Kadang & 48 & 45 & 3 & 0,33729 & \\
\hline & Jarang & 86 & 77 & 9 & 0,483568 & \\
\hline Search & Tidak Pernah & 33 & 21 & 12 & 0,94566 & \\
\hline
\end{tabular}

Dari Tabel 3. di atas dapat terlihat bahwa atribut Search memiliki nilai gain yang lebih tinggi, sehingga atribut search menjadi root dari pohon keputusan berdasarkan algoritma C4.5 dan berikut ini gambar pohon keputusan hasil pemodelan yang telah dilakukan:

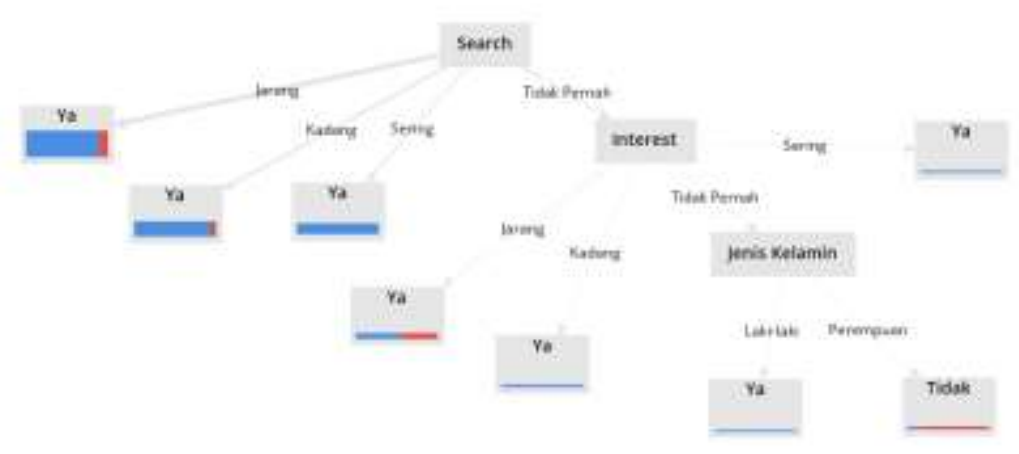

\subsection{Evaluation}

\section{Gambar 4. Pohon Keputusan}

Untuk melihat hasil evaluasi dari model sebelumnya yang dieksekusi dengan software Rapidminer, yaitu dengan melihat akurasi yang ditampilkan pada proses tersebut. Adapun tabel akurasi yang didapatkan adalah sebagai berikut: 


\begin{tabular}{|c|c|c|c|}
\hline & true Ya & true Tidak & dass precision \\
\hline pred. Ya & 173 & 20 & $89.64 \%$ \\
\hline pred. Tidak & 3 & 4 & $57.14 \%$ \\
\hline dass recal & $98.30 \%$ & $16.67 \%$ & \\
\hline
\end{tabular}

\section{Gambar 5. Akurasi pada Confusion Matrix}

Dari gambar 5 di atas, terlihat bahwa tingkat akurasi dari rule yang dihasilkan pada penelitian ini adalah sebesar $88.50 \%$. Nilai accuracy, sensitivity, specificity, ppv, dan $n p v$ dapat dilihat dari perhitungan berikut ini:

accuracy $=\frac{t p+t n}{t p+t n+f p+f n} \quad$ accuracy $=\frac{173+4}{173+4+3+20} \quad$ accuracy $=0,885(88,5 \%)$

sensitivity $=\frac{t p}{t p+f n} \quad$ sensitivity $=\frac{173}{173+20} \quad$ sensitivity $=0,8964(89,64 \%)$

specitivity $=\frac{t n}{t n+f p} \quad$ specitivity $=\frac{4}{4+3} \quad$ specitivity $=0,5714(57,14 \%)$

$p p v=\frac{t p}{t p+f p} \quad p p v=\frac{173}{173+3} \quad p p v=0,983(98,3 \%)$

$n p v=\frac{t n}{t n+f n} \quad p p v=\frac{4}{4+20} \quad p p v=0,1667(16,67 \%)$

Sedangkan evaluasi yang divisualisasikan menggunakan kurva ROC untuk algoritma C4.5 tergambar pada gambar 6 berikut ini:

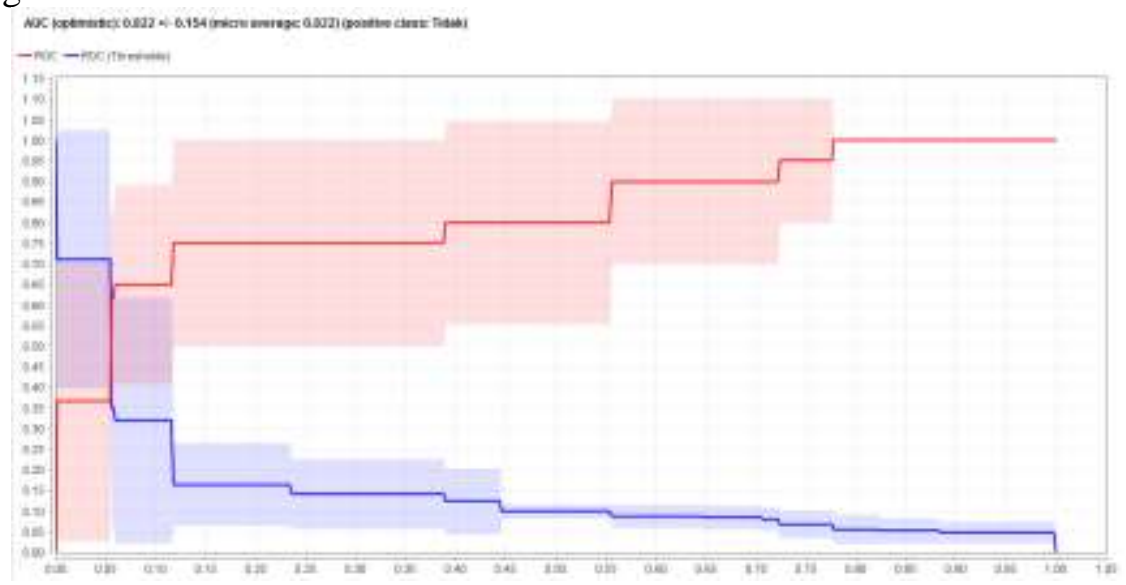

Gambar 6. Grafik ROC

\section{Kesimpulan}

Dari pembahasan di atas dapat disimpulkan bahwa pemasangan iklan tanpa label harga berpengaruh terhadap pola pembelian konsumen, dimana atribut yang paling berpengaruh adalah atribut Search (pencarian) dan atribut Interest (ketertarikan). Sedangkan dalam penelitian ini atribut Share (Ulasan) tidak digunakan hal tersebut dikarenakan sedikit atau kurangnya konsumen yang 
melakukan Share (Ulasan) saat melihat iklan tanpa label harga. Dengan demikian bahwa penggunaan iklan tanpa label harga dinilai cukup efektif untuk melakukan promosi produk bagi pengiklan dengan memperhatikan aspek pemberian informasi kontak pengiklan serta pembuatan caption iklan yang menarik sehingga aspek pencarian (search) dan ketertarikan (interest) konsumen dapat dipenuhi.

Efektivitas dari model yang didapatkan pada penelitian ini dapat terlihat dari prosentase akurasi yang terbentuk yakni sebesar $88.50 \%$ dan Nilai AUC(Area Under Curvee) adalah sebesar 0.82 yang artinya klasifikasi yang dihasilkan termasuk ke dalam kelompok Good Classification. Hal ini karena klasifikasi Performance keakurasian AUC dengan rentang nilai antara 0.80-0.90 termasuk kelompok Good Classification [15]

\section{REFERENSI}

[1] Napoleoncat.com, "Instagram users in Indonesia," napoleoncat.com, 2020. https://napoleoncat.com/stats/instagram-users-in-indonesia/2020/05 (accessed Nov. 16, 2020).

[2] A. M. Dewi, "Pengaruh Iklan Online Melalui Instagram Terhadap Keputusan Pembelian bagi Peningkatan Penjualan Produk Kuliner Lokal," Ekonika J. Ekon. Univ. kadiri, vol. 3, no. 1, p. 1, 2018, doi: 10.30737/ekonika.v3i1.78.

[3] N. Amira and I. K. Nurhayati, "Efektivitas Fitur Instagram Sponsored sebagai Media Iklan/Promosi (Studi pada Iklan Tiket.com dengan Metode EPIC Model)," J. Media Commun. Sci., vol. 2, no. 2, pp. 116-126, 2019.

[4] N. S. Apriliana and E. P. Utomo, "Pengaruh Intensitas Melihat Iklan di Instagram terhadap Pengetahuan dan Perilaku Konsumtif Remaja Putri," J. Komun., vol. 13, no. 2, pp. 179-190, 2019, doi: 10.20885/komunikasi.vol13.iss2.art5.

[5] Luthfiyatillah, A. N. Millatina, S. H. Mujahidah, and S. Herianingrum, "Efektifitas Media Instagram Dan E-Wom ( Electronic Word Of Mouth ) Terhadap Minat Beli Serta Keputusan Pembelian," J. Penelit. Ipteks, vol. 5, no. 1, pp. 101-115, 2020.

[6] R. Haryanto and A. Rahmi, "Strategi Promosi Melalui Media Sosial Instagram Guna Menarik Generasi Milenial untuk Memilih Produk Tabungan pada PT Bank Pembangunan Daerah Kalimantan Selatan Cabang Paringin," Inovbiz J. Inov. Bisnis, vol. 7, no. 2, p. 213, 2019, doi: 10.35314/inovbiz.v7i2.1109.

[7] W. Sastika, "Epic Model: Pengukuran Efektivitas Iklan Kuliner Melalui Sosial Media Instagram @Kulinerbandung Sebagai Media Promosi," JTIM - J. Teknol. Inf. Manaj., vol. 1, no. 01, p. 21, 2018, doi: 10.25124/jtim.v1i01.1531.

[8] J. Han, M. Kamber, and J. Pei, Data mining: Data mining concepts and techniques, Third. United States of America: Elsevier, 2014.

[9] I. H. Witten, E. Frank, and M. a Hall, Data Mining: Practical Machine Learning Tools and Techniques. United States of America: Diane Cerra, 2011.

[10] J. Suntoro, Data Mining: Algoritma dan Implementasi Dengan Pemrograman PHP. Jakarta: PT Elex Media Komputindo, 2019.

[11] M. A. Sobarnas And Iskandar, "Komparasi Akurasi Metode K-Nearest Neighbor Dan C4.5 untuk Customer Relationship Management pada Perusahaan Pembiayaan," Infotech J. Inform. Teknol., Vol. 1, Pp. 1-14, 2020.

[12] Y. I. Kurniawan, "Perbandingan Algoritma Naive Bayes Dan C.45 Dalam Klasifikasi Data Mining," J. Teknol. Inf. Dan Ilmu Komput., Vol. 5, No. 4, Pp. 455-464, 2018, Doi: 10.25126/Jtiik.

[13] Y. Mardi, "Data Mining: Klasifikasi Menggunakan Algoritma C4.5," J. Edik Inform., Vol. 2, No. 2, Pp. 213-219, 2017.

[14] Y. Suhanda, I. Kurniati, and S. Norma, "Penerapan Metode Crisp-DM dengan Algoritma KMeans Clustering Untuk Segmentasi Mahasiswa Berdasarkan Kualitas Akademik," J. Teknol. Inform. dan Komput. MH Thamrin, vol. 6, no. 2, pp. 12-20, 2020.

[15] E. Fitriani, "Perbandingan Algoritma C4.5 dan Naive Bayes Untuk Menentukan Kelayakan Penerima Bantuan Program Keluarga Harapan,” SISTEMASi, vol. 9, no. 1, pp. 103-115, 2020. 